\title{
Verb second as a function of Merge
}

\author{
Jan-Wouter Zwart
}

\section{Introduction}

A verb second (V2) construction is one in which the verb (by rule) appears directly after the first constituent. In this paper I propose to describe V2 as the positional marking of a dependency relation.

The approach assumes that there is only one structure generating procedure in syntax, which is applied iteratively to the output of a previous application, Merge:

Merge

Add $x$ to $y$ yielding $\langle x, y\rangle$

I hypothesize that Merge as defined in (1) automatically creates a dependency relation $S$ (for sisterhood) where $x$ is invariably the antecedent (or nondependent) and $y$ the dependent. ${ }^{1}$

I suggest furthermore that $S$ can be (and perhaps universally is) marked on $y$, and spelled out on one of the terms of $y$. The proposal of this paper is that this dependency marking may be realized in two ways: by inflectional morphology (tense, agreement marking) or by position. In particular, the proposal is that $\mathrm{V} 2$ is positional marking of the relation between a fronted element and its sister, to the effect that the term of $y$ spelling out $S$ is realized as the leftmost element in $y$.

It can be seen that $\mathrm{V} 2$, on this proposal, is really a verb-first requirement applied to the domain of the dependent in a dependency relation. This eliminates a property that has always been commented on as strange, namely reference to an arbitrary number (two) in the description of the pattern. It raises the question, though, why no V-last counterpart to V2 seems to exist (i.e. no pattern that requires fronting of $x$, creating $\langle x, y\rangle$, to be accompanied by realization of the verb on the right edge of the dependent $y$ ). I suggest that the verb in V2-constructions is a member of a larger class of elements described as 'linkers', appearing more generally in constructions of predication or modification.

We define linker as in (2):

\section{Linker}

A linker is a left-edge element of $y$ appearing only when $y$ is a dependent.

Linkers, then, are positional markers appearing as a function of Merge.

There is no general requirement that a linker be a shifted term of the dependent $y$, it may also be a dummy element. While the V2-position is realized by a shifted verb in languages like Dutch, English uses either auxiliary verbs or dummies like did:

$$
\begin{array}{ll}
\text { a. } & \text { John kissed Mary } \\
\text { b. Why did John kiss Mary ? }
\end{array}
$$

In (3b), $x=$ why, $y=$ John kiss Mary, and did is the linker between $x$ and $y$ appearing at the left edge of $y$.

It will be seen that the linker, if present, is the designated element spelling out morphological 
dependency between $x$ and $y$ in $\langle x, y\rangle$ as well. If $x$ is a tense operator, the linker may be a dummy expressing tense, capturing Warlpiri-type V2 effects, and, more generally, the 'tense-second' phenomena discussed by Koster (2003).

The approach suggests that verb-first (V1) clauses (in languages showing V2 otherwise) are themselves dependents, so that the V1-effect is identical to the V2-effect, with the antecedent $x$ unexpressed. ${ }^{2}$

The proposal made here will remain silent on the phrase structural realization of the linker (the left-edge element). There appears to be no objection to viewing the linker's position as a head position, staying close to the analysis of V2 shaped by X'-theory (e.g. Chomsky 1986:6). However, the analysis does not allow us to predicate any properties of that head position, in particular, to describe any agency to that head position or to any morphosyntactic features residing in it. In other words, our proposal entails that V2 is not triggered by the need to acquire, check, assign or eliminate formal features, and that there is at best an indirect connection with the presence of tense or agreement features within the clause. I submit that connections between morphosyntactic features and verb placement, if there are any, are to be explained by a consistency requirement of the type in (4):

\section{Consistency}

If $\alpha$, a term of $y$, spells out a dependency of $y$ positionally, it also does so morphologically.

(4) follows on the conjecture that the linker in a dependent $y$ (i.e. the verb in a V2 construction) has no other function than to spell out the dependency of $y$ towards some $x$. Importantly, (4) works only in one direction, since not all languages employ the device of positional marking, and few languages (if any) employ it in all constructions.

\section{General V2 properties}

The general aspects of the V2-phenomenon that the proposed analysis covers are:

(5) General aspects of V2

a. $\quad \mathrm{V} 2$ is the side-effect of a fronting operation

b. Modulo parametric variation, $\mathrm{V} 2$ is insensitive to the type of element fronted

Traditional approaches to V2 concentrate on a general requirement forcing the verb (in independent clauses) to move to a position (C) occupied by the complementizer in embedded clauses. A second operation then moves an arbitrary category to a position to the left of $\mathrm{C}$ (later identified as the specifier position of $\mathrm{CP}$ ), triggered by the V2 constraint:

\section{The V2 constraint}

The verb must be second

The V2 constraint (6) is unsatisfactory in that it predicates some requirement of the verb and triggers movement of some other category. Moreover, the movements satisfying the V2 constraint (subject placement, topicalization, expletive insertion, wh-movement) exist in non-V2 languages as well, suggesting that other triggers, bearing no relation to V2, are in force. If we take these triggers seriously, we may have to formulate the V2-phenomenon as in (7), with (7b) replacing the V2-constraint (6) when YP $(=\langle x, y\rangle)$ is the root: 


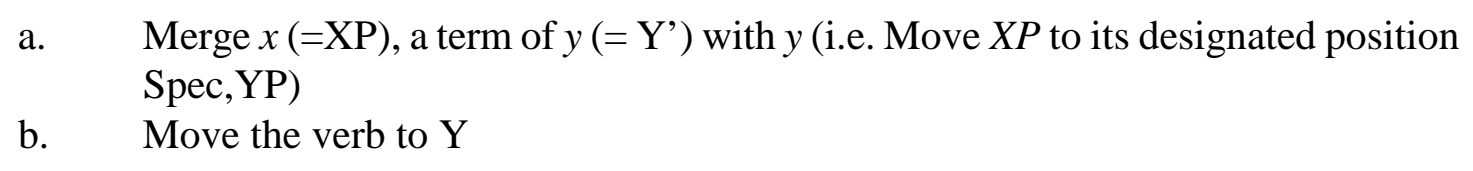

We thus see a shift from a particular verb-movement trigger accompanied by generic XPmovements to particular (triggered) XP-movements accompanied by a generic verb movement. This shift entails that the target for the XP-movement (and hence the target for verb movement) may be variable, leading to a more dynamic analysis of the V2 pattern where the verb does not always occupy the position C (see Travis 1984, 1991; Zwart 1993) and a more dynamic analysis of clause structure more generally (Zwart 2003-2004). Discussion of this issue (cast in terms of a symmetric vs. asymmetric analysis of V2 by Schwartz \& Vikner 1989, 1996) needs to focus on the target of XP-movement, rather than on the target of verb movement.

The general aspects of the V2 phenomenon in (5), captured more or less successfully by traditional approaches to $\mathrm{V} 2$, are covered by the analysis proposed here as well.

\section{Problems associated with V2}

More interesting are particular problematic phenomena associated with the V2-pattern, some of which are listed in (8):

(8) Difficult facts associated with V2

a. V2 asymmetries (between main and embedded clauses; construction specific ones; having to do with finiteness);

b. nonstandard V2 phenomena (quotative inversion, conjunction-triggered inversion, apokoinou constructions);

c. V2 deviations (V1, V3, verbs that fail to undergo V2).

\subsection{V2 asymmetries}

Whether or not a language uses positional marking must be stipulated for each dependency. In Germanic, and perhaps universally, positional marking appears to be limited to dependencies marking the end of a cycle.

We define a cycle as a finite sequence of operations Merge. A cycle is constituted as specified in (9):

Cycle

A cycle is constituted: (a) when no further operation Merge takes place, or

(b) when the nondependent is a lexical term (i.e. a noun, verb, or adjective), or

(c) in elsewhere cases.

This means that a root clause will constitute a cycle (a case of (9a)) and that the combination of a verb and an embedded clause will also constitute a cycle (a case of (9b)). The elsewhere cases in $(9 \mathrm{c})$ are needed for language and construction specific variation.

Subject-initial root clauses, then, are the result of a sequence of operations Merge constituting a cycle. The final dependency relation, where $x=$ the subject and $y=$ the subject's sister, is positionally marked in Continental West-Germanic and North Germanic, with the finite verb appearing as a linker at the left edge of $y$. The situation is different with embedded clauses, where 
a cycle is ended only where $x=\mathrm{V}$ and $y=$ the embedded clause. In that case, the complementizer appears to function as the linker marking the dependency positionally. But the dependency between the subject of the embedded clause and its sister is not positionally marked, as this dependency does not mark the end of a cycle.

More generally, we can say that the positional marking property applies to each dependency, but is passed on to each next dependency (taking the derivation to proceed in a bottom up fashion) until the end of a cycle is reached.

The proposal that the complementizer is a positional dependency marker explains a curious and hitherto unexplained fact, namely that the specifier position of a declarative complementizer (dat in Dutch, dass in German, etc.) may not be occupied. Thus, fronting of an adverb in a root clause yields V2, but fronting across $\mathrm{C}$ in embedded clauses is impossible. Instead, the fronted adverb appears to the right of the complementizer (examples from Dutch):

$$
\begin{aligned}
& \text { a. Gisteren heeft Jan Marie gekust } \\
& \text { yesterday has John Mary kiss-PART } \\
& \text { 'Yesterday John kissed Mary.' } \\
& \text { b. * Ik heb gezegd [ gisteren dat Jan Marie gekust } \\
& \text { I have say-PART yesterday that John Mary kiss-PART } \\
& \text { heeft ] } \\
& \text { has ] } \\
& \text { c. Ik heb gezegd [ dat gisteren Jan Marie gekust } \\
& \text { I have say-PART that yesterday John Mary kiss-PART } \\
& \text { heeft ] } \\
& \text { has ] }
\end{aligned}
$$

Languages using positional dependency marking, then, may differ as to which dependency they choose to mark positionally. Nothing excludes that a language views the combination of a subject and its sister in an embedded clause as the end of a cycle in need of positional marking (one of the elsewhere cases in (9c)). This yields the embedded V2 phenomenon of Icelandic and Yiddish. ${ }^{3}$

Construction specific asymmetries are in evidence in residual V2 languages like English, where only the fronting of particular operator-like elements sets up a dependency which is positionally marked (as in (3b)). Here, little more needs to be said. As before, the positional marking requirement disappears in embedded clauses, suggesting that the relevant cycle is established only after merger with the matrix clause verb:

$$
\text { I wonder why (*did) John kiss Mary }
$$

It is, however, remarkable that Germanic embedded interrogatives are rarely positionally marked when the embedded interrogative does not correspond to a yes/no-question:
a. I wonder if John kissed Mary
b. I wonder (*if) why John kissed Mary 
But cases like (12b) do exist, as noted by Hoekstra (1994) for the Dutch dialect spoken in the city of Amsterdam:

We moeten eens vragen of waar die heen
we must once ask-INF if where DEM DIR.PRT
'We should ask where he's going.'

Moreover, some Germanic dialects allow complementizers to appear after the wh-phrase (example from Dutch):

Ik wou weten waarom of dat Jan dat gedaan had
I wanted know-INF why if that John that do-PART had
'I wanted to know why John did that.'

Whereas positional marking of the sister of the wh-phrase could be countenanced as the outcome of parameter setting, it is unclear why the linker should be a complementizer rather than the verb.

In fact, Spoken Afrikaans does use the verb as a linker in embedded wh-questions (example from Biberauer 2002:37):

Ek wonder wat het hy vandag weer aangevang
I wonder what has he today again started
'I wonder what he started today again.'

Similarly, dialects of English spoken in Northern Ireland use a dummy verb as the linker between the verb and its complement clause and between the wh-phrase and its sister in embedded whquestions (Henry 1995:105ff; data from Adger 2003:343):

(16) a. I asked did Medea poison Jason

b. I asked who did Medea poison

One possibility explaining the anomaly of the choice of linker in (14) could be that Dutch uses the complementizer as a dummy linker in these particular cases, on analogy with embedded yes/no-questions.

Another asymmetry connected with $\mathrm{V} 2$ is that between finite and nonfinite verbs. Infinitives are apparently never called upon as positional dependent markers (i.e. they do not undergo V2), barring the exceptional Frisian IPI-cases discussed in Hoekstra (1997) and Zwart (2001). Nonfinite clauses in Dutch appear in two types of constructions, extraposed (17a) and interlaced with the matrix clause (17b):
probeerde (om)
het boek te lezen
that John tried for the book to read-INF
b. ..dat Jan het boek probeerde (*om) te lezen that John the book tried for to read-INF

Both: '..that John tried to read the book.'

We may take the complementizer om in extraposed infinitive clauses as a dummy positional dependent marker (a linker), blocking verb movement as in finite embedded clauses. In the type 
of (17b) (traditionally referred to as 'verb raising'), material belonging to the embedded clause (such as het boek 'the book' in (17b)) is remerged to a constituent containing the matrix verb (probeerde 'tried' in (17b)), and the verbs appear to form a cluster. The embedded clauses in this type of construction are generally taken to be defective or transparent, suggesting that in our terms they will not constitute a cycle. If so, no positional dependent marking is called for.

A related construction is the nominal infinitive, where the lexical head is a nonfinite verb contained within a nominal constituent (DP):

$$
\begin{aligned}
& \text { dat vervelende altijd maar stripboeken lezen } \\
& \text { that boring:ADJ always just comic-books read-INF } \\
& \text { 'this boring (habit of) reading comic books all the time' }
\end{aligned}
$$

Here we see no argument for thinking any subpart of the DP constitutes a cycle. The question of why no V2 takes place in nominalizations then reduces to the question of why no positional dependent marking takes place within DP. Here we have nothing new to contribute. ${ }^{4}$

\subsection{Nonstandard V2 phenomena}

These include various types, some of which have received little or no treatment in the theoretical literature.

\subsubsection{Quotative inversion}

Most familiar will be the type of quotative inversion (Collins and Branigan 1997):

$$
\text { I am so sick said John } \quad\left({ }^{\sqrt{ }} \text { John said }\right)
$$

In English, quotative inversion is optional, apparently a residu of earlier English where V2 was much more pervasive. In strict V2 languages like Dutch and German it is obligatory:

$$
\begin{array}{llllll}
\text { Ik voel } & \text { me zo } & \text { ziek } & \text { zei } & \text { Jan } & \text { (*Jan zei) } \\
\text { I feel } & \text { me so sick } & \text { said } & \text { John } &
\end{array}
$$

Let us call the part exemplified by said John/zei Jan the quotative, and the part preceding the quotative the quote. The prosodic properties of the quotative, then, suggest that it be treated as backgrounded material: the intonation is low and flat, shown by Zwart (2002) to be characteristic of backgrounding in Germanic.

Backgrounding can be illustrated in various constructions, the most familiar of which will be right dislocation (example from Dutch, with small print indicating low pitch):

$$
\begin{array}{llllll}
\text { Ik } & \text { ken } & \text { hem } & \text { niet die jongen } \\
\text { I } & \text { know him not that boy }
\end{array}
$$

Zwart (2002) argues that backgrounded material is generated in a high specifier position (i.e. merged last, in a bottom-up derivation), after which the remainder of the clause moves across it to the left (i.e. is remerged with the backgrounded material), inverting both the hierarchical and the linear ordering:

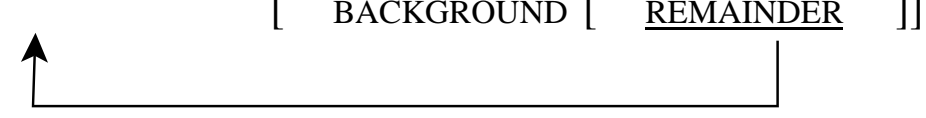


The remainder can be a fully expanded clause, as in (23):

$$
\begin{aligned}
& \text { Waar komt hij vandaan die jongen ? } \\
& \text { where comes he hence that boy }
\end{aligned}
$$

The wh-phrase waar 'where' indicates that the remainder should be a CP, with V2 triggered by the fronting of the wh-phrase. It follows that the backgrounded material must occupy a position beyond $\mathrm{CP}$, which is currently uncharted territory.

If quotative inversion involves backgrounding, the quote $=$ the remainder and the quotative $=$ the background. Quotative inversion then takes place in a part of the structure that is beyond $\mathrm{CP}$. On current understanding, the target for the $\mathrm{V}$-movement is not $\mathrm{C}$ and is not associated with any formal features triggering the verb. That makes it a nonstandard V2-phenomenon.

On the approach to V2 attempted here, quotative inversion is just another case of positional dependent marking. When the quote raises across the quotative, a dependency is created in which the quote $=x$ (the antecedent) and the quotative $=y$ (the dependent), and the verb appears at the left edge of the dependent.

\subsubsection{Conjunction induced inversion}

Another nonstandard V2-phenomenon is conjunction-induced inversion, scorned by normative grammarians, but attested in many Germanic dialects at one stage or other:

$\begin{array}{lllllll}\begin{array}{l}\text { Alles is } \\ \text { all is }\end{array} & \text { now } & \begin{array}{l}\text { reeds already } \\ \text { settled and }\end{array} & \begin{array}{l}\text { bepaald } \\ \text { can I herein }\end{array} \\ \text { tot mijn } & \text { spijt } & \text { moeilijk } & \begin{array}{l}\text { veranderingen } \\ \text { changes }\end{array} & \begin{array}{l}\text { maken } \\ \text { make }\end{array}\end{array}$

'Everything is already settled and it is regretfully difficult for me to make any changes.'

(from a Dutch letter by Jan Toorop, 1858-1929, in Van der Horst \& Van der Horst 1999:298)

It is attested in (at least) Old and Middle English (Kellner 1924:289-290), Old, Middle, and Early Modern High German (Paul 1919:78-81; Behaghel 1932:31-36), Middle and Early Modern Dutch, surviving in written Dutch until around 1930 (Stoett 1923:231; Van der Horst \& Van der Horst 1999:296-299), Old Swedish (De Boor 1977:195), and Old French (Foulet 1963:120, 287). It was originally certainly a feature of the spoken language, witness its appearance in isolated dialects such as Siberian Mennonite Low German (Jedig 1969:145).

This type of construction, called Aunt Betty in the Dutch tradition ('Tante Betje', after Charivarius 1940), is problematic for traditional approaches to V2, since the element inducing it is not a phrase but a head (the conjunction en 'and'). But if we follow Kayne (1994) and Munn (1993) in taking coordination to involve regular X'-structure, with the conjunction taking the second member of the coordination as its complement, merge establishes a pair $\langle x, y\rangle$ with $e n$ $=x$ (the antecedent) and $y$ (the dependent $)=$ the second member of the coordination: 


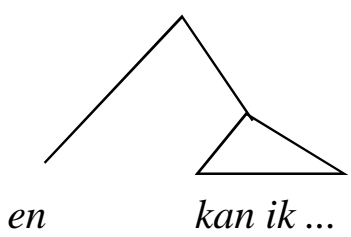

If we then take the combination of a conjunction and the second member to constitute a cycle, the inversion in the second member can again be described as positional dependent marking.

More generally, traditional approaches to V2 are unable to account for inversion not triggered by fronting of a phrase. The approach contemplated here is insensitive to the phrase structure status of the antecedent in the relevant dependency.

Another V2 construction which may be discussed in this context is Icelandic Stylistic Inversion, where the $\mathrm{V} 2$ pattern crucially involves a subject gap and the fronting of a single word (a participle, negation, or adverb):

Ég hélt að kysst hefðu hana margir stúdentar
I thought that kiss:PART had her many
'I thought that many students had kissed her.'

As pointed out by Anderson (2000), this construction is not easily accommodated in traditional $\mathrm{V} 2$ accounts, since, as with conjunction-induced inversion, the fronted element triggering V2 is not a phrase but a head. In our approach, V2 is positional marking of a dependent category, the antecedent of which may be a head or a phrase.

\subsubsection{Apokoinou constructions}

A third non-standard V2-phenomenon features in apokoinou constructions (Dutch 'herhalingsconstructies') of the type studied in De Vries (1910-1911: chapter 5) and Jansen (1981: chapter 7), where the finite verb appears twice: ${ }^{5}$

$$
\begin{array}{lllllll}
\text { En } & \text { dan } & \text { was } & \text { je } & \text { tegenstander } & \text { was } & \text { neer } \\
\text { and } & \text { then } & \text { was } & \text { your } & \text { opponent } & \text { was } & \text { down }
\end{array}
$$

While there appear to be various subtypes, the one illustrated in (27) can be analyzed as involving competition between the subject je tegenstander 'your opponent' and the topic dan 'then' for the first position of the clause (cf. Zwart 1998:383). Abstracting away from verb placement, we get the following dependencies:

$$
\begin{aligned}
& \text { a. } \mathrm{S}_{1}<\text { je tegenstander, neer was }> \\
& \text { b. } \mathrm{S}_{2}<\text { dan, je tegenstander neer was }>
\end{aligned}
$$

The apokoinou construction then results when both $S_{1}$ and $S_{2}$ show positional dependent marking (i.e. V2) with the antecedent of $S_{1}$ ending up as the pivot in the final construction (called 'overloopdeel' in Sassen 1967).

In this connection it is important to note that the apokoinou construction is a single utterance, consituting one prosodic domain (featuring only one nuclear pitch accent, on neer 'down' in (27)) and with various local dependencies holding between the parts preceding and following the pivot, including Negative Polarity Item (NPI) licensing (29a), selection (29b), and focus association (29c) (the pivot is in square brackets): 


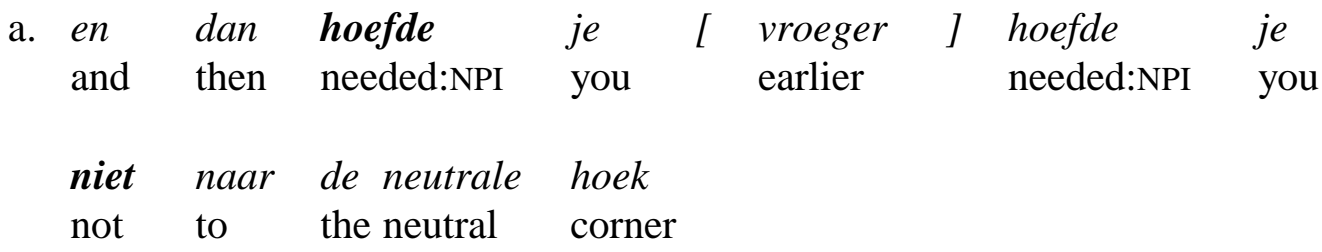

'In the old days you were not required to go to the neutral corner.'

b. ik sta me [ op een morgen ] sta ik me

I stand me:REFL on a morning stand I me:REFL

te scheren

to shave

'I'm shaving myself one morning.'

c. maar ik heb [ toen WEL ] heb ik [ toen drie keer but I have then FOC-PRT have I then three times

kort na mekaar ] heb ik toen tegen Van Dam

short after each other ] have I then against Van Dam

gebokst

fought

'But I did fight against Van Dam in those days, three times shortly after one another.'

In (29a), the NPI hoefde 'needed' preceding the pivot is licensed by the negation niet 'not' in the part following the pivot. In ( $29 \mathrm{~b}$ ) the reflexively used first person object pronoun $m e$ 'me' in the part preceding the pivot is selected by the verb scheren 'shave' in the part following the pivot. In (29c), a double apokoinou construction, the affirmative focus particle wel in the part preceding the second pivot (it is in fact the pivot of the first apokoinou construction) is associated with the focused object Van Dam in the part following the second pivot.

In another type of apokoinou construction, the pivot is not a subject but a focused constituent (also (29c)):

$$
\begin{aligned}
& \begin{array}{lllllllll}
\text { ik heb [ nooit van mijn leven }] & \text { heb } & \text { ik een } & \text { wedstrijd } \\
\text { I have } & \text { never of } & \text { my life } & \text { have } & \text { I a } & \text { match }
\end{array} \\
& \text { gebokst die gemaakt was } \\
& \text { fought REL fixed was }
\end{aligned}
$$

'Never in my life have I fought a match that was fixed.'

In those cases, the subject also appears twice (ik in (29c) and (30)). Here the competition appears to be between a focus-initial and a subject-initial construction, yielding the pairs in (31) for (30):
a. $\mathrm{S}_{1}<$ nooit van mijn leven, ik een match gebokst heb... >
b. $\mathrm{S}_{2}<i k$, nooit van mijn leven heb ik een match gebokst... > 
What is special about this type is the doubling of the subject in addition to the doubling of the verb. Accepting this as a special feature, the verb placement follows as described above, as positional marking of the dependent in each pair.

Another remarkable feature of the apokoinou construction is that the two verbs need not be identical. In those cases, the first (leftmost) verb is always less specific than the second:

$\left.\begin{array}{lllllllll}\begin{array}{l}\text { Dat } \\ \text { that }\end{array} & \text { was } & \text { in '35 } & \text { in } 1935\end{array}\right] \begin{aligned} & \text { zal } \\ & \text { MOD:PROB that }\end{aligned}$

'That must have been in 1935.'

Here a verbal complex consisting of a modal auxiliary zal, a perfective auxiliary zijn 'be', and a participle geweest 'been' is doubled by the simple copula was 'was'. This might be taken as an indication that the doubled (leftmost) verb in the apokoinou construction is really a dummy, which may or may not be identical to the original verb.

\subsection{V2 deviations}

Languages characterized by the V2 phenomenon regularly show deviations from the V2 pattern in which the verb shows up in first (V1) or third (V3) position (see Thráinsson 1986 for an early discussion). On our approach, these deviating patterns arise under two related circumstances:

(33) a. V1: the cycle functions as a dependent

b. V3: the dependent functions as a cycle

In other words, given a pair $\mathrm{M}=\langle x, y\rangle$ with tree structure representation (34), the unmarked case is that where $\mathrm{M}$ constitutes a cycle, $y$ is a dependent. The special cases in (33) then specify that either $\mathrm{M}$ is a dependent (in addition to being a cycle) or $y$ is a cycle (in addition to being a dependent).

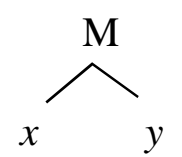

Positional dependency marking that spells out a verb at the dependent left edge then yields V1 if $\mathrm{M}$ is a dependent and V3 if $y$ is a cycle.

It remains to determine, then, under what circumstances these special situations may occur.

\subsubsection{V1}

V1 constructions in Dutch are never independent declarative expressions. They can be classified as in (35): 
a. yes/no-questions

Kom je ook?

come you too

'Are you coming too?'

b. imperatives

Kom (jij) nou eens op tijd!

come you now once on time

'Be on time for a change!'

c. conditionals

Kom je op tijd dan kun je mee eten come you on time than can you with eat 'Be on time and you can join us for dinner.'

d. counterfactuals

$\begin{array}{llllllll}\text { Was } & j i j & \text { op tijd } & \text { gekomen } & \text { dan } & \text { was } & \text { er } & \text { niks } \\ \text { was } & \text { you } & \text { on time } & \text { come-PART } & \text { then } & \text { was } & \text { there } & \text { nothing }\end{array}$

gebeurd

happen-PART

'If you had been on time, nothing would have happened.'

e. narrative inversions (connected discourse constructions)

Kom ik daar binnen, zegt die vent...

come I there inside says that guy

'So I come in, and this guy says ...'

f. topic drop

Ken ik niet

know I not

'Don't know him/her/it.'

For most of these construction types, an analysis has been proposed in which the first constituent is an empty operator (see Katz \& Postal 1964, Baker 1971, Huang 1984, Zwart 1997:219 among others). If so, these reduce to ordinary V2 constructions.

A solid piece of argumentation in defense of empty operators in these constructions revolves around the fact that each V1 construction allows just a single interpretation, i.e. a topic drop construction cannot at the same time be interpreted as a yes/no-question or a conditional, etc. (Cardinaletti 1990). This suggests that each construction involves a designated empty element. 
It has been noted, however, that the empty operator itself has to be "sanctioned by preceding discourse or by pragmatics" (Cardinaletti 1990:78). This raises the question whether the operator cannot be dispensed with if the construction as a whole is viewed as a dependent of some factor of discourse organization or pragmatics.

In connection with this, it may be noted that the empty operator $(\mathrm{Q})$ proposed for yes/noquestions is argued by Katz \& Postal (1964:97) and Baker (1970:197) to be present in both yes/no-questions and wh-questions. If so, and if a fronted wh-phrase triggers inversion in whquestions, it is not clear what triggers inversion in yes/no-questions. Also relevant is the observation that a declarative clause with the proper intonation is interpreted as a yes/noquestion:

Je komt oOK?
you come too
'You're coming too?'

This shows that the inversion does not correspond directly to a particular aspect of the semantics, but rather (as Katz \& Postal 1964) argue, to pragmatics: whereas (36) expresses surprise about a state of affairs, (35a) expresses a request for information. We may hypothesize that yes/noquestions are dependents of an implicit statement of the type 'I ask', in which case the construction as a whole indeed functions as a dependent.

Similarly, then, with imperatives, where the implicit statement conveys a directive (cf. Katz \& Postal's 1964:76 I-morpheme). Again, neutral order V2-clauses may also function as imperatives, but these are not imperatives in the performative sense: ${ }^{6}$

a. Je trouwt met Govert!
$\begin{aligned} & \text { you marry with Govert } \\ & \text { 'You are going to marry Govert!' }\end{aligned}$
b. Je MOET met Govert trouwen!
you must with Govert marry
'You must marry Govert!'

In connection with this, it is perhaps relevant that true imperatives lack an addressee subject:

$$
\begin{aligned}
& \text { Trouw (\#jij) met Govert! } \\
& \text { marry you with Govert } \\
& \text { 'Marry Govert!' }
\end{aligned}
$$

If the imperative is dependent of an implicit performative of the type 'I order you', the addressee is already included in the antecedent and need not (perhaps cannot) be repeated.

That conditionals and counterfactuals are not independent utterances needs no argumentation. ${ }^{7}$ Finally, in narrative inversions and topic drop constructions, the element of discourse connectedness is obvious. We propose that, rather than stating that an empty operator is present which requires sanctioning by preceding discourse, the expression as a whole is a direct dependent of the relevant discourse factor.

Summarizing, V1 constructions in V2-languages are all characterized by a perceived dependency of the construction as a whole to some factor of discourse organization or pragmatics. We submit that under these circumstances, the expression as a whole is viewed as a dependent, with concomitant positional marking by left edge spell-out of the verb. 


\subsubsection{V3}

V3-orders are commonplace in residual V2 or non-V2 languages (like Modern English), but we are interested here in V3-orders in strict V2-languages. Residual V2-languages with a history of strict V2 appear to have lost V2 in topicalizations first, then in subject-initial declarative constructions, and finally in wh-constructions. Thus we find reports of Dutch dialects with strict V3-orders in topicalizations (data from the dialect of Oostende, Winkler 1874:364):

Zonder entwat te zeggen Wansje loat zen zwiins achter
without something to say $\quad$ Wansje leaves his pigs behind
'Without saying anything, Wansje leaves his pigs behind.'

The finite verb loat 'lets' in (39) is adjacent to the verb, as in ordinary subject-initial V2constructions, suggesting that the combination of a subject and its sister is taken to constitute a cycle in this dialect. It follows that the topic in cases like this is 'extracyclic': the operation merge creating the pair <zonder entwat te zeggen, Wansje loat ...> does not count as a cycle.

Since similar V3-orders do not occur (in the relevant dialects) where the first constituent is a wh-phrase, it must be the nature of the antecedent $(x)$ that determines whether or not a cycle is constituted. Loss of V2 can then be described as the gradual progression of extracyclicity across types of fronted constituents.

The concept of extracyclicity is also helpful in describing structural V3-orders of the type in (40) (from Dutch):
a. Jan die ken ik niet
John DEM:NNTR know I not 'John, I don't know.'
b. Dat het regent dat verbaast me niet
that it rains that amazes me not
'That it's raining does not amaze me.'

In (40a), a fronted constituent is resumed by an agreeing demonstrative (NNTR = nonneuter gender), which itself triggers inversion. We can say that the pair consisting of the demonstrative and its sister constitutes the cycle relevant for positional dependent marking (i.e. V2), while the fronted constituent itself is extracyclic. Accepting Koster's (1978) analysis of subject clauses as in (40b), in which fronted clauses are invariably resumed by a possibly silent demonstrative, we conclude that fronted clauses are always extracyclic.

Other cases of V3 cannot be described as involving an extracyclic first constituent. In these cases, the second constituent appears to have a special status. This applies, arguably, to French Complex Inversion, where fronting of a wh-phrase triggers movement of the finite verb around a subject clitic to the $\mathrm{V} 3$ position:
a. Jean il est venu
John SCL is come-PART
'John came.'
b. Pourquoi Jean est il venu?
why John is SCL come-PART
'Why did John come?'


The doubling of the subject suggests that one of the pair Jean/il is the subject, and the independent character of the subject clitic (not affixed to the verb) suggests that $i l$ is in fact the real subject. On our approach, this implies that there is a dependency between pourquoi 'why' $=$ the antecedent $(x)$ and il est venu 'he came' $=$ the dependent $(y)$, with the position of est again a function of positional dependent marking. The doubling subject Jean apparently does not disrupt this dependency organization.

I propose to describe the subject in French Complex Inversion, or any element appearing between an antecedent and its dependent as 'extradependent'. We may think of the extradependent as an interpolation, since (41b) alternates with (42a) but not with (42b):

$$
\begin{aligned}
& \text { a. Pourquoi est il venu? } \\
& \text { why is SCL come-PART } \\
& \text { 'Why did he come?' } \\
& \text { b. * Pourquoi Jean est venu? } \\
& \text { why John is come-PART }
\end{aligned}
$$

Dutch has a limited number of 'extradependent' elements, all sentence connecting adverbs like echter 'however', nu '(nontemporal) now', dan '(nontemporal) then', immers 'as is known', and daarentegen 'in contrast':
a. Dit voorstel echter is onacceptabel this proposal however is unacceptable
b. In diezelfde landstreek $\quad$ nu waren herders in that-same countryside now were shepherds 'Now there were shepherds in that same countryside.'

Prosodically, these unstressed adverbs group with the first constituent:
a. Dit voorstel echter dat is onacceptabel this proposal however DEM:NTR is unacceptable 'This proposal however is unacceptable.'
b. * Dit voorstel dat echter is onacceptabel this proposal DEM:NTR however is unacceptable

This prosodic property of this class of adverbs may trigger the proposed 'extradependency'. Alternatively, we might suppose that the positional spell-out rule (left edge dependent marking) which we argue yields V2 is sensitive to prosodic grouping, such that the left edge position be defined as the first position following enclitic materical.

When stressed, these adverbs can be used in first position, without triggering V2 (this works less well with $n u$ and dan, which arguably have to remain unstressed and trigger V2 when placed in first position):

$$
\begin{aligned}
& \text { Echter, dit voorstel is onacceptabel } \\
& \text { however this proposal is unacceptable }
\end{aligned}
$$


b. $\quad \mathrm{Nu}$ waren er herders in diezelfde landstreek

now were there shepherds in that-same countryside

'Now there were shepherds in that same countryside.'

In our terminology, this means that these adverbs, when stressed and sentence-initial, are extracyclic. As such they form part of a larger group of speech act adverbials discussed by Meinunger (2004:73f) for German (examples from Dutch):
a. Eerlijk, dit voorstel is onacceptabel honest this proposal is unacceptable
b. * Eerlijk is dit voorstel onacceptabel honest is this proposal unacceptable

As Meinunger notes, a speech act adverb like eerlijk 'honest' can be seen as short for eerlijk gezegd 'honestly said', which may or may not trigger inversion:
Eerlijk
honest
gezegd is dit
voorstel
proposal
onacceptabel say-PART is this
unacceptable
b. Eerlijk
gezegd dit
voorstel
honest
Say-PART this
proposal is unacceptable

Both: 'Honestly put, this proposal is unacceptable.'

Meinunger observes that the longer forms are unambiguous speech act adverbials, whereas (some of) the shorter forms could also be taken to apply to the propositional content. An example illustrating the ambiguity involves tussen haakjes 'in parentheses', of which only a non-speech act reading is available when it triggers inversion:
a.
Tussen haakjes
dit
voorstel is
onacceptabel between parentheses this proposal is unacceptable 'By the way, this proposal is unacceptable.'
b. Tussen haakjes is dit voorstel onacceptabel between parentheses is this proposal unacceptable 'This proposal is unacceptable when presented parenthetically.'

When expanded to tussen haakjes gezegd 'said parenthetically, by the way', the ambiguity disappears (only the speech act reading is available), and inversion is optional.

Adapting Meinunger's observation to our proposal, we can say that extracyclicity is applied to certain fronted adverbials if a speech act reading must be enforced. This suggests that speech act material is in principle extracyclic in Germanic, yielding V3, but that unambiguous speech act material may be included in a cycle, generalizing the V2 pattern.

Another class of V3 constructions appears in Mainland Scandinavian (Platzack 1986, Egerland 1998, Nilsen 2002). These involve focus-sensitive adverbs like Norwegian bare '(nontemporal) just' and nesten 'almost' (Norwegian data from Nilsen 2002:152): 

a. Jens bare gikk
John just left
b. Jens nesten gråt
John almost cried

In these constructions, the finite verb is focused, and the particular reading expressed here ('John simply/virtually left/cried') is lost when the adverb is realized to the right of the verb. A similar class of adverbs blocks V2 in German, but in contrast to Norwegian, the V3 order is not allowed, leading to a situation where these adverbs can be used only in embedded clauses or with analytic tenses (Meinunger 2001, 2004; German examples from Meinunger 2004:56):
a. ...weil die Kommission nichts als meckerte because the committee nothing but grumbled '..because the committee did nothing but grumble'
b. Die Kommission hat nichts als gemeckert the committee has nothing but grumble-PART 'The committee did nothing but grumble.'
c. * Die Kommission meckerte nichts als the committee grumbled nothing but

Meinunger observes that the relevant class of adverbials needs to be proclitic to some host to its right, which is absent in (50c).

What is not explained is why the V3-order of Norwegian is not available to German. In our terms, we might state that whereas focus sensitive adverbs may be extradependent in Norwegian, they may not in German. Alternatively, we might attribute the Norwegian pattern to a spell-out mechanism which orders two elements competing for the left edge of a dependent (the verb and the focus sensitive adverb) in a particular way not available to German. ${ }^{8}$

\subsubsection{Verbs that fail to undergo $V 2$}

The German facts in (50) are reminiscent of another class of verbs that fail to undergo V2, namely those associated with both a particle and prefix of derivational morphology (Koopman 1995, Vikner 2002). The problem here is that while particles are stranded under V2, prefixes are not, and that in embedded clauses the prefix precedes both the particle and the verb (example from Dutch):

$\begin{aligned} & \text { op-voeren } \\ & \text { up-carry 'to stage' } \\ & \text { re-up-carry }\end{aligned}$ 'to stage anew'
a. ..dat ze het stuk (her-)opvoeren
that they the play re-stage
'..that they are staging the play (again)'
b. Ze (*her-)voeren het stuk op
they re-carry the play up
'They are (re-)staging the play.'




c. Ze voeren het stuk (*her) op
they carry the play re up
'They are (re-)staging the play.'
d. * Ze her-opvoeren het stuk
they re-stage the play

Our proposal has nothing particular to say about the restriction displayed by these facts. Arguably, the verb heropvoeren is a backformation from the noun heropvoering 'restaging', which comes with a recoverability requirement blocking reordering of the morphemes involved.

\section{The relation of $\mathrm{V} 2$ to morphology}

The approach to V2 outlined here presupposes that syntactic and morphosyntactic dependencies are invariably sisterhood relations. It follows that subject-verb agreement is not a relation between the subject and the verb, but between the subject and its sister, with the subject the antecedent and the sister the dependent. The dependency may then be spelled out on a term of the sister, which, in the Germanic languages is invariably the verb.

In this approach, agreement is not mediated by a functional head, and features residing in functional heads are not taken to be responsible for verb movement in any way. It follows that V2 is not triggered by morphosyntactic features.

In the literature, the only morphosyntactic feature taken to be directly involved with V2 is TENSE or finiteness, sometimes notated $[+\mathrm{F}]$ (e.g. Den Besten 1978). The approach outlined here takes tense morphology on the verb to be the spell-out of a dependency relation between a tense operator (the antecedent) and its sister (the dependent), which contains the verb. In other words tense morphology on the verb is formally identical to agreement morphology, i.e. the spell-out of a dependency on a term of the dependent element.

We take it to be uncontroversial that the feature TENSE is located outside the verb phrase (i.e. tense is a clausal property). It follows that TENSE is not an inherent feature of the verb, and indeed verbs may appear without tense, e.g. in nominalizations. However, the idea that TENSE is located in (or constitutes) a functional head assumes a theory of morphosyntactic dependency which we have abandoned here, namely a theory where morphology is the function of a direct dependency between a lexical and a functional head. Since such dependencies are not sufficiently local (they do not involve sisterhood), we propose that the grammar lacks them entirely. We submit that TENSE be viewed as an operator merged to the structure at some point in the derivation, creating a dependency which is spelled out on a term of the dependent element, leaving the question of whether TENSE is a functional head or a phrasal operator moot.

The relevance of tense to V2 may then be stated in the following terms: the element designated to spell-out tense dependency is also the element designated for positional dependent marking (a subcase of the consistency principle (4)). We do not see any evidence beyond sheer conjecture that tense is more directly involved in the V2 phenomenon (a point shared with Anderson 2000).

Agreement morphology is often taken to be relevant to the question of whether V2 is generalized to embedded clauses or not, with 'rich' morphology forcing generalized V2 (yielding what Vikner 1995:131 calls 'V-to-I languages'). On our view, generalized V2 results when merger of a subject invariably yields a cycle, i.e. a dependency requiring positional dependent marking.

This raises the question what 'richness' of morphology contributes to the system of grammar 
we are contemplating. We take agreement morphology on the verb to be the morphological spellout of a relation between the subject and its sister, a larger constituent containing the verb. Richness of morphology addresses the structure of the morphological paradigm of the verb spelling out the agreement relation, hence is twice removed from the actual syntactic dependency relation triggering agreement and/or V2. It is not obvious, in the system we are considering, that richness of morphology of the verbal paradigm should be in any way related to a requirement of positional dependency marking of the dependent containing the verb.

In this connection it may be useful to point out that the theory we are contemplating makes no use of a distinction between 'strong' and 'weak' morphosyntactic features. Previously, the association of strong features with rich paradigms may have had some intuitive appeal. But in a system where features do not trigger movements, there is no need for a distinction between strong and weak features, and the supposed correlation with rich morphology loses much of its appeal. This is quite apart from the circumstance that it has proved difficult to define the exact cut-off point between rich and poor morphology in connection with generalized V2.

\section{A note on OT approaches to $\mathrm{V} 2$}

The approach to V2 discussed here bears some resemblance to analyses of V2 proposed within the framework of Optimality Theory (OT) (Anderson 2000, Legendre 2001). I outline the differences here.

In the OT-approaches to V2, the placement of the verb is described as the interaction of two constraints familiar from prosodic morphology, of which one requires the verb to be leftmost (EDGEMOST (L)) and another bars the verb from initial position (NONINITIAL). If both constraints are ranked high with respect to other relevant constraints, and are ordered as in (53), the V2 pattern results. ${ }^{9}$

$$
\operatorname{NonINitial~}\left(\mathrm{V}_{\text {fin }}, \mathrm{S}\right) \gg \operatorname{EdgeMost}\left(\mathrm{V}_{\text {fin }}, \mathrm{L}, \mathrm{S}\right)
$$

On our approach, the circumstance that the verb appears in the second position does not follow from an interaction of constraints, but from the following set of assumptions:

(54) a. Dependency is a function of binary merge, yielding $\langle x, y\rangle$

b. In each pair $\langle x, y\rangle$, the relation between $x$ and $y$ is marked on $y$ (dependent marking)

c. Dependent marking can be morphological or positional marking

d. The element marking a dependency morphologically is the designated element for marking the dependency positionally

e. Positional marking is done by lexicalizing the left edge of the dependent (i.e. the positional marker is a linker)

We take all of (54) to hold universally, with languages differing as to which dependencies they choose to mark, and how (i.e. morphologically and/or positionally). The V2 pattern then results when positional marking of the highest pair $\langle x, y\rangle$ in the clause is done by the verb.

It will be seen that what the approaches have in common is the aspect of linearization (cf. also Chomsky 2001), but that the approach advanced here relates V2 to the derivational process of Merge, to the configurational properties of the output of Merge, and to a general theory of dependency marking.

It follows from the approach advanced here that the verb in V2 constructions occupies the position to the left of the first constituent, not to the left of the first word (unlike second position 
phenomena involving clitics). This is because the first word of a complex first constituent is in a local dependency configuration where its sister does not contain the verb. Unlike Anderson (2000) we need not invoke any conditions on movement or syntactic well-formedness to obtain this result.

It also follows that Wackernagel (1892:428) was right in questioning a general relation between V2 and second position clitic placement. Wackernagel conjectures that since V-final is common Indoeuropean, V2 is an innovation which may have started out with 'light' (one or two syllable) verbs as a subcase of his law fronting light elements. But he admits that there is little evidence for this scenario (and in fact counterevidence from Celtic and Greek), listing only second position copula placement in Latin and Lithuanian as relevant cases outside Germanic. ${ }^{10}$

From our perspective, second position copula placement is indeed related to V2, but not in terms of prosodic properties. Adopting a Small Clause analysis of copula constructions (Kayne 1984), copula constructions often involve raising of the Small Clause predicate to subject position, yielding a dependency which may need positional marking. One possibility is that the copula is such a positional dependent marker, a clausal counterpart to linkers found more generally in the nominal domain (Den Dikken and Singhapreecha 2004).

\section{Conclusion}

In this paper I have argued for the following. The basic (in fact, only) structure building operation in the computational system of human language, Merge, creates a pair of sisters, one of which is the dependent of the other. In particular, when a constituent is fronted, the element it adjoins to (its sister) becomes its dependent. Dependency may be marked in two ways: morphologically or positionally. Morphological marking occurs when a term of the dependent (in the Germanic languages, this is the verb or an auxiliary) is marked for features which the nondependent carries inherently (agreement). The particular proposal of this paper is that positional marking occurs when a term of the dependent is realized at the left edge of the dependent, functioning as a linker. In V2 languages, the designated element for positional dependent marking is the element which marks the same dependency morphologically as well, i.e. the finite verb. Verb second, then, is really verb first applied to the domain of the dependent of a fronted constituent.

The proposal allows us to incorporate a range of recalcitrant $\mathrm{V} 2$ phenomena within a unified theory of V2. These phenomena include the well-known asymmetries associated with V2 (between main and embedded clauses, between finite and nonfinite verbs), nonstandard V2 phenomena (such as quotative inversion, conjunction-triggered inversion, and apokoinou constructions), as well as deviations from the V2 pattern (V1 and V3).

It is suggested that verb placement needs to be studied in the context of a theory of linkers expressing a relation between two elements joined by Merge, rather than in terms of features residing in functional heads triggering overt or covert head movement. 


\section{Notes}

1. We write the product of Merge as an ordered pair rather than as a set, on the proposal of Zwart (2004) that Merge transfers one element at a time from the numeration to the current derivation (instead of selecting two elements and combining them in a symmetric fashion). The dependency discussed in the text is taken to be the automatic consequence of the process of asymmetric Merge, assuming that Merge turns the current stage of the derivation into a dependent (or the argument of a newly added functor).

2. The properties of consistent verb initial languages are arguably not comparable to those of $\mathrm{V} 1$ constructions in V2 languages.

3. As is well known, the embedded V2 phenomenon of Mainland Scandinavian, Frisian, and Colloquial Dutch is qualitatively different, requiring that these embedded clauses be viewed as root clauses; in other words, viewing the combination of the subject and its sister in these constructions as a cycle is not a parametric option but a necessity.

4. Note that the determiner dat can be replaced by a possessive Jan z' $n$ 'John his', where $z$ ' $n$ arguably functions as a linker.

5. The examples in this subsection are all Colloquial (Rotterdam) Dutch, taken from Jules Deelder, 2001, The Dutch Windmill (Amsterdam: De Bezige Bij), an apparently verbatim transcript of an interview with Dutch boxing legend Bep van Klaveren (1907-1992) on his life and career, which contains over one hundred examples of apokoinou constructions. Source page numbers are indicated with each example. (Thanks to Elzerieke Hilbrandie-Van Hooijdonk for assistance in compiling the corpus.)

6. In (37a), a future state of affairs is presented as a matter of fact; in (37b) the modal verb conveys the notion of obligatoriness or necessity.

7. See Iatridou and Embick (1994) for an analysis of conditional inversion.

8. Nilsen (2002) takes the Norwegian facts to suggest that verb movement in Norwegian involves masked XP-movement, so that the finite verb occupies a specifier rather than a head position.

9. The constraints specify a domain over which the linearization requirements hold ( $\mathrm{S}$, the clause) and an element to which they apply, the finite verb.

10. Wackernagel also lists V2 examples from Ancient Greek votive inscriptions, which seem to have special syntactic properties. 


\section{References}

Adger, D. 2003. Core syntax. Oxford: Oxford University Press.

Anderson, S. 2000. "Towards an optimal account of second position phenomena." In Optimality Theory: syntax, phonology and acquisition, J. Dekkers, F. van der Leeuw and J. van de Weijer (eds), 301-333. Oxford: Oxford University Press.

Baker, C.L. 1970. "Notes on the description of English questions: the role of an abstract question morpheme." Foundations of Language 6: 197-219.

Behaghel, O. 1932. Deutsche Syntax: eine geschichtliche Darstellung IV. Heidelberg: Carl Winters.

den Besten, H. 1978. "Auxiliary deletions and the interplay between local deletive rules and filters." Paper presented at the GLOW Colloquium, Amsterdam.

Biberauer, T. 2002. "Verb second in Afrikaans: is this a unitary phenomenon?" Stellenbosch Papers in Linguistics 34: 19-70.

de Boor, H. 1977. Studien zur altschwedischen Syntax. Hildesheim: Georg Olms.

Cardinaletti, A. 1990. "Subject/object asymmetries in German null topic constructions and the status of Spec,CP.” In Grammar in progress: GLOW essays for Henk van Riemsdijk, J. Mascaró and M. Nespor (eds), 75-84. Dordrecht: Foris.

Charivarius. 1940. Is dat goed Nederlands? Amsterdam: Ploegsma.

Chomsky, N. 1986. Barriers. Cambridge: MIT Press.

Chomsky, N. 2001. "Derivation by phase.” In Ken Hale: a life in language, M. Kenstowicz (ed), 1-52. Cambridge: MIT Press.

Collins, C. and P. Branigan. 1997. "Quotative inversion.” Natural Language and Linguistic Theory 15: 1-41.

den Dikken, M. and P. Singhapreecha. 2004. "Complex noun phrases and linkers." Syntax 7: 154.

Egerland, V. 1998. "On verb-second violations in Swedish and the hierarchical ordering of adverbs." Working Papers in Scandinavian Syntax 61: 1-22.

Foulet, L. 1963. Petite syntaxe de l'ancien français. Paris: Librairie Honoré Champion.

Henry, A. 1995. Belfast English and Standard English: dialect variation and parameter setting. New York: Oxford University Press.

Hoekstra, E. 1994. "Overtollige voegwoorden en de volgorde of + interrogativum/ relativum." De Nieuwe Taalgids 87: 314-321. 
Hoekstra, J. 1997. The syntax of infinitives in Frisian. University of Groningen dissertation.

van der Horst, J. and K. van der Horst. 1999. Geschiedenis van het Nederlands in de twintigste eeuw. The Hague: SDU/Antwerp: Standaard.

Huang, C.-T.J. 1984. "On the distribution and reference of empty pronouns." Linguistic Inquiry 15: 531-574.

Iatridou, S. and D. Embick. 1994. "Conditional inversion.” Proceedings of NELS 24: 189-203.

Jansen, F. 1981. Syntaktische konstrukties in gesproken taal. Amsterdam: Huis aan de drie grachten.

Jedig, H.H. 1969. Očerki po sintaksisu niznenemeckogo govora Altaiskogo kraja. Omsk.

Katz, J.J. and P.M. Postal. 1964. An integrated theory of linguistic descriptions. Cambridge: MIT Press.

Kayne, R.S. 1984. Connectedness and binary branching. Dordrecht: Foris.

Kayne, R.S. 1994. The antisymmetry of syntax. Cambridge: MIT Press.

Kellner, L. 1924. Historical outlines of English syntax. London: MacMillan and Co.

Koopman, H. 1995. “On verbs that fail to undergo verb-second.” Linguistic Inquiry 26: 137-163.

Koster, J. 1978. "Why subject sentences don't exist." In Recent transformational studies in European languages, S.J. Keyser (ed), 53-64. Cambridge: MIT Press.

Koster, J. 2003. “All languages are tense-second." In Germania et alia: a linguistic Webschrift for Hans den Besten, J. Koster and H. van Riemsdijk (eds)

http://odur.let.rug.nl/ koster/DenBesten/contents.htm

Legendre, G. 2001. "Masked second-position effects and the linearization of functional features." In Optimality-theoretic syntax, G. Legendre, J. Grimshaw, and S. Vikner (eds), 241-277. Cambridge: MIT Press.

Meinunger, A. 2001. "Restrictions on verb raising." Linguistic Inquiry 32: 732-740.

Meinunger, A. 2004. "Interface restrictions on verb second." Linguistics in Potsdam 22: 51-81.

Munn, A. 1993. Topics in the syntax and semantics of coordinate structures. University of Maryland dissertation.

Nilsen, Ø. 2002. “V2 and Holmberg's Generalization.” In Studies in comparative Germanic syntax: proceedings from the 15th workshop on Comparative Germanic Syntax, J.-W. Zwart and W. Abraham (eds), 151-173. Amsterdam: John Benjamins.

Paul, H. 1919. Deutsche Syntax IV: Syntax (Erste Hälfte). Halle: Niemeyer. 
Platzack, C. 1986. “COMP, INFL and Germanic word order.” In Topics in Scandinavian syntax, L. Hellan and K. Koch Christensen (eds), 185-234.

Sassen, A. 1967. "Syntactische implicaties van de zgn. herhalingsconstructie ('dat is een gek geval is dat')." Handelingen Vlaams filologencongres 26: 30-47.

Schwartz, B. and S. Vikner. 1989. "All verb second clauses are CPs." Working Papers in Scandinavian Syntax 43: 27-49.

Schwartz, B. and S. Vikner. 1996. "The verb always leaves IP in V2 clauses." In Parameters and functional heads, L. Rizzi and A. Belletti (eds), 11-62. New York: Oxford University Press.

Stoett, F.A. 1923. Middelnederlandse spraakkunst: syntaxis. The Hague: Martinus Nijhoff.

Thráinsson, H. 1986. "V1, V2, V3 in Icelandic." In Verb second phenomena in Germanic languages, H. Haider and M. Prinzhorn (eds),169-194. Dordrecht: Foris.

Travis, L. 1984. Parameters and effects of word order variation. Dissertation, MIT.

Travis, L. 1991. "Parameters of phrase structure and V2 phenomena." In Principles and parameters in comparative grammar, R. Freidin (ed), 339-364. Cambridge: MIT Press.

Vikner, S. 1995. Verb movement and expletive subjects in the Germanic languages. New York: Oxford University Press.

Vikner, S. 2002. "Immobile complex verbs in Germanic." To appear in Journal of Comparative Germanic Syntax.

de Vries, W. 1910-1911. Dysmelie: opmerkingen over syntaxis. Groningen: Municipal Gymnasium.

Wackernagel, J. 1892. “Über ein Gesetz der indogermanischen Wortstellung.” Indogermanische Forschungen 1: 333-436.

Winkler, J. 1874. Algemeen Nederduitsch en Friesch dialecticon. The Hague: Martinus Nijhoff.

Zwart, J.-W. 1993. Dutch syntax: a minimalist approach. Dissertation, University of Groningen.

Zwart, J.-W. 1997. Morphosyntax of verb movement: a minimalist approach to the syntax of Dutch. Dordrecht: Kluwer Academic Publishers.

Zwart, J.-W. 1998. "Where is syntax? Syntactic aspects of left dislocation in Dutch and English." In The limits of syntax, P. Culicover and L. McNally (eds), 365-393. San Diego: Academic Press.

Zwart, J.-W. 2001. "Syntactic and phonological verb movement." Syntax 4: 34-62.

Zwart, J.-W. 2002. "Backgrounding in Dutch.” Paper presented at CGSW 17.

Zwart, J.-W. 2003-2004. "Een dynamische structuur van de Nederlandse zin; deel 1: dynamische 
syntaxis." Tabu 33: 55-71.

Zwart, J.-W. 2004. “The format of dependency relations.” Lecture series at the 2004 Syntax Fest, Indiana University, Bloomington, June18 - July 1. 